\title{
Lesson Learnt from Cardiovascular Risk Factors Studies in Urban Population of Jakarta and House Hold Survey in Indonesia, 1988 - 2018.
}

\author{
Dede Kusmana', Budhi Setianto', Sutedjo', Bastaman Basuki²
}

\section{Introduction}

$\longrightarrow$

The Framingham Heart Study was initiated in the United States in the year 1946 demonstrating correlations between several risk factors and coronary artery disease, left ventricular hypertrophy, and heart failure. ${ }^{1}$

Reports by the World Heart Federation showed that the cardiovascular mortality in developing countries was on the rise, contrasting to those of developed countries. Indonesia is in need of field cardiovascular laboratory (mobile cardiovascular laboratory?) to obtain data regarding cardiovascular risk factors on a community level in order to formulate an appropriate public health policy. ${ }^{2-7}$

On the year 1988, the director of National Cardiovascular Center Harapan Kita Hospital (NCCHK), Doctor Sukaman, initiated the Monica Jakarta Survey which was supported by Professor Georgi,

I Department of Cardiology and Vascular Medicine,

2 Department of Community Medicine. Medical Faculty of University of Indonesia, National Cardiovascular Center, Harapan Kita Hospital , Jakarta.

\section{Correspondence:}

Prof.dr.Dede Kusmana

Department of Cardiology and Vascular Medicine, Department

of Community Medicine, Faculty of Medicine Universitas

Indonesia

E-mail: dede_kusmana@yahoo.com

(Indonesian J Cardiol. 2019;40: 269-274)

a representative from World Health Organization (WHO). A survey by Community Health Care and NCCHK was done on the three districts in the South Jakarta. These districts were selected due to the stable population (minimal immigration and emigration). 7,8

The Monica surveys were conducted in the year 1988, 1993, and 2000; unfortunately, it was discontinued due to changes in WHO policy worldwide. This lead to discontinuation of Monica Jakarta study. In short, we learn that organized intervention on a community level through Stop Smoking and Regular Exercise campaigns has a positive impact on the prevalence of cardiovascular risk factors.

On the year 2007, we proceed with the similar study design and rename the project into Jakarta Cardiovascular Survey which was funded and supported by the Government. Our results showed an increase in the prevalence of these cardiovascular risk factors compared to the year 1993-2007, probably due to discontinuation of organized intervention and campaigns from the year 2000 to 2007.9,10

From Monica Jakarta, Jakarta Cardiovascular Study, and other studies worldwide; we learn that continuing and revitalized organized intervention and campaigns on the community level are crucial to control the prevalence of cardiovascular risk factors in the community. 


\section{Methods}

The respondents of the study were recruited from three districts of South Jakarta namely Mampang Prapatan, Kebayoran Baru, and Cilandak. These districts were known as a laboratory community under the supervision of the National Cardiovascular Center Harapan Kita. Field surveys were conducted prior to study surveys to collect the data of respondents; the study surveys were done in the year 1988, 1993, 2000, and 2007.7,8 2013 and 2018 data were collected from Riskesdas report year 2013 and 2018.

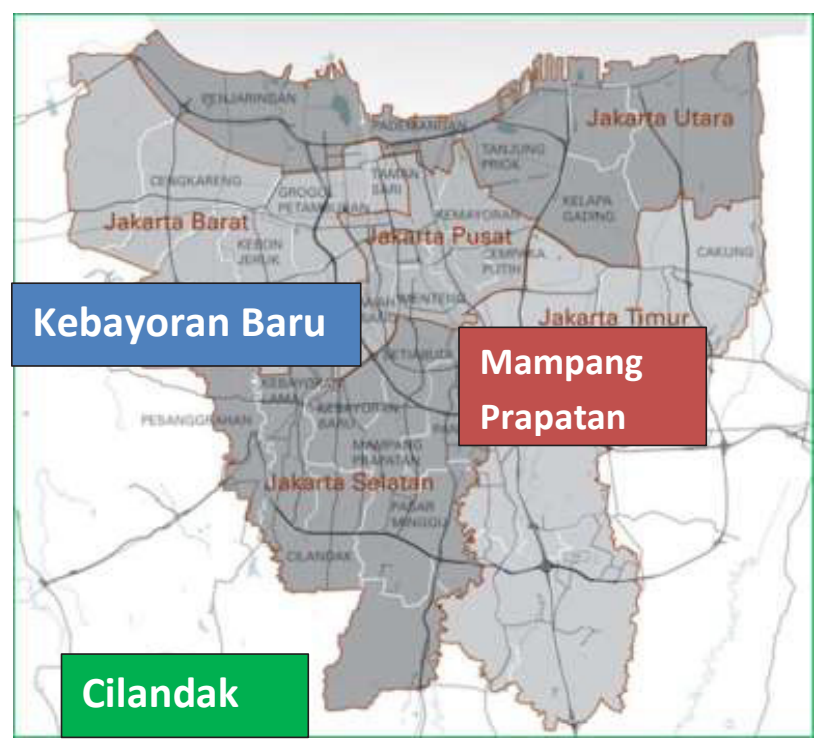

Fig. 1. The Location of Monica Jakarta Program

We used a multistage-stratified-cluster sampling method accumulating approximately 2000 respondents from a total of 523.000 population. The age ranges from 25-64 years. A complete questionnaire was used to assess the respondents, in addition to physical examination, 12 leads electrocardiogram and laboratory examination.

We used the same methods for the studies conducted in the year 1993, 2000, and 2007.

Our study showed a rise in cardiovascular risk factors in 1993 compared to 1998. In the year 2000, we introduced a lifestyle intervention spearheaded by trained health personnel in order to promote smoking cessation and regular exercise (callisthenics exercise/ Indonesian style "Senam Jantung Sehat", walking and jogging program). They used leaflets/pamphlets and visits home. Unfortunately, no organized intervention was performed in the year 2000 to 200, leading to a concomitant rise in the prevalence of cardiovascular risk factors.

Hypertension was classified as recommended by WHO (Monica Manual) for 1988, 1993 and 2000, and JNC -7 for 2007 study. Body Mass Index defined as Obesity for $>30 \mathrm{~kg} / \mathrm{m} 2$ and $>27 \mathrm{~kg} / \mathrm{m} 2$ respectively. $7,9,10$ ECG was recorded and interpreted using the Minnesota code. Data were prospectively collected and analyzed using IBM SPSS software (for Window 10). Statistical significance was set at a p-value of $<0.05$ (two-tailed).

\section{Results}

The ethnic groups did not change significantly for at least 20 years (Table 1), although few areas were excluded due to city development.

Table 1 . Characteristics of Respondents

\begin{tabular}{lcccc}
\hline \multicolumn{1}{c}{ Ethnics } & 1988 & 1993 & 2000 & 2007 \\
\hline Javanese & $917(44.2$ & 985 & $819(44,1$ & 474 \\
& $\%)$ & $(48.9 \%)$ & $\%)$ & $(44.9 \%)$ \\
Batavian & $708(34.2$ & $600(29.8$ & $602(32,4$ & 374 \\
& $\%)$ & $\%)$ & $\%)$ & $(35.4 \%)$ \\
Sundanese & $294(14.2$ & 247 & 244 & $142(13.4$ \\
& $\%)$ & $(12.3 \%)$ & $(13,1 \%)$ & $\%)$ \\
Minang & $72(3.5 \%)$ & $88(4.4 \%)$ & $69(3,7 \%)$ & $33(3.1$ \\
& & & & $\%)$ \\
Batak & $28(1.4 \%\}$ & $29(1.5 \%)$ & $45(2,4 \%)$ & $24(2,3$ \\
& & & & $\%)$ \\
Bugis & - & $4(0.2 \%)$ & $13(0.7 \%)$ & $6(0.6 \%)$ \\
Ambon & - & $3(0.1 \%)$ & $9(0.5 \%)$ & $2(0.2 \%)$ \\
Balinese & - & $6(0.3 \%)$ & $7(0.4 \%)$ & $6(0.6 \%)$ \\
Chinese & - & $3(0.1 \%)$ & $3(0.2 \%)$ & $3(0,2 \%)$ \\
Others & $54(2.6 \%)$ & $47(2.7 \%)$ & $45(2.4 \%)$ & $31(2,9 \%)$ \\
Total & 2073 & 2012 & 1856 & 1095 \\
& $(100 \%)$ & $(100 \%)$ & $(100 \%)$ & $(100 \%)$ \\
\hline
\end{tabular}

\section{Discussion.}

The late Dr. Sukaman, first director of National Cardiovascular Center Harapan Kita Hospital initiated Monica Jakarta Surveys, and Jakarta Cardiovascular Survey is similar to Framingham Study with a modified population, were conducted in three districts of South Jakarta. Table 1 showed a similar baseline percentage of the Population in three districts over several years which fulfil the criteria for the stable study population. The 
Table 2. Cardiovascular Risk Factors and Abnormal ECG

\begin{tabular}{|c|c|c|c|c|c|c|c|}
\hline & \multicolumn{2}{|c|}{ Smoking } & \multicolumn{2}{|c|}{ Hypertension } & \multicolumn{2}{|c|}{ Obesity } & \multirow{2}{*}{$\begin{array}{c}\text { ECG } \\
\text { Both }(\%)\end{array}$} \\
\hline & M (\%) & $\mathrm{F}(\%)$ & $\mathrm{M}(\%)$ & $\mathrm{F}(\%)$ & $\mathrm{M}(\%)$ & $\mathrm{F}(\%)$ & \\
\hline 1988 & 59.5 & 5.9 & 13.6 & 16 & 2.3 & 7.3 & 2.3 \\
\hline 1993 & 56.9 & 6.4 & 16.5 & 17 & 3.7 & 10 & 2.9 \\
\hline 2000 & 38.5 & 1.8 & 12.1 & 12.2 & 6.1 & 15.8 & 1.2 \\
\hline 2007 & 36.8 & 3.6 & 17.6 & 13.3 & 19.8 & 31.87 & 4.2 \\
\hline
\end{tabular}

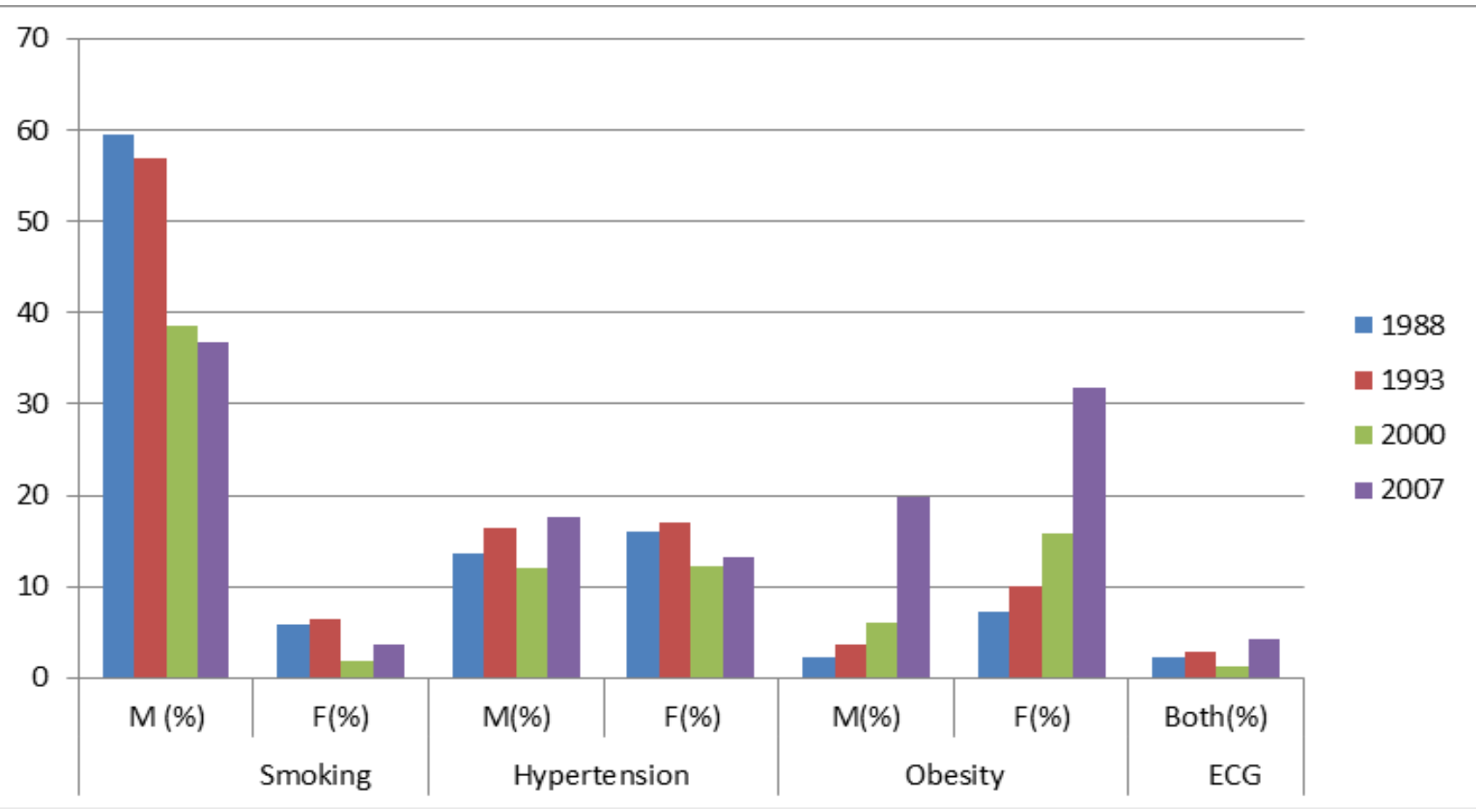

results revealed that Javanese, Batavian and Sundanese were the majority population in the three studies. Buginese, Ambonese, Balinese and Chinese emerges in the 1993 population.

The Monica Jakarta Team decided to conduct an intervention programme to lower the prevalence of smoking, hypertension, and Obesity since there was no intervention done before. The Healthy Lifestyle Programme was introduced with the support of the National Cardiovascular Center Harapan Kita and Department of Cardiology, Indonesian Heart Foundation and Community Health Center from the Government of Jakarta City.

The medical doctors, nurses and other health providers were regularly trained for this program. Indonesian Heart Foundation made pamphlets and brochures "Panca Usaha Jantung Sehat" or the five ways to have a healthy heart. The Indonesian Heart Club
Exercise trainers from Indonesia Heart Foundation encouraged people to join these exercise programmes. The exercise program was done for at least 2 to 3 times per week spanning from 30 to 60 minutes.

\section{What do we learn from these surveys?}

\section{Smoking}

Monica Jakarta and Jakarta Cardiovascular Study team collaborated with a non-governmental organization (Indonesian Heart Foundation, LM3, Indonesian Heart Association, and others) and Government for an anti-smoking campaign. These programmes showed satisfying results, with a decreased number of smokers by $18.4 \%$ in 7 years from $56.9 \%$ on the year 1993 to $38.5 \%$ on the year 2000 equal to $2.6 \%$ per year. If such intervention is done today, a further reduction of 
$13 \%$ can be achieved in 5 years and another $13 \%$ on the following 5 years, finally achieving a 30\% decrease based on MDGs recommendation. Other factors should not be underestimated; government legislation may have an extensive influence. By forbidding smoking in public areas, the government has successfully reduced the number of smokers; a study showed that the level of education in the country is inversely associated with the number of smokers. ${ }^{11}$ Literacy index, although not an exact measure of the level of education has been shown to steadily increasing in Indonesia and may contribute to the decreased smokers. ${ }^{12} \mathrm{~A}$ higher level of education may also mean a more receptive audience on anti-smoking campaigns. A study in China showed that income was unrelated to the prevalence of smokers and may explain why the increase in Gross Domestic Product (GDP) did not lead to an increased number of smokers.

\section{Hypertension}

Definition of hypertension in the year 1988 was Systolic Blood Pressure $>159 \mathrm{mmHg}$ and Diastolic > $94 \mathrm{mmHg}$ on medication and or without medication according to Monica Manual, nearly equivalent to JNC 7 definition of stage 2 hypertension. Hence, only stage 2 hypertension from the year 2007 was included in the comparison. The prevalence of hypertension in males increased from $13.6 \%$ in 1988 to $16.5 \%$ in 1993 . After the intervention, the prevalence was significantly reduced to $12.1 \%$ in the year 2000 . Meanwhile, the prevalence of stage 2 hypertension in the year 2007 was $17.6 \%$. In females, the prevalence increased from $16 \%$ in 1988 to $17 \%$ in 1993 . After the intervention, it decreased to $12.2 \%$ in the year 2000 and rebounded to $13.33 \%$ in the year 2007 . The combined stage 1 and stage 2 hypertension has a prevalence of $44.4 \%$ and $40.11 \%$, this further decreased in the year 2018 to a combined male and female prevalence of $34.1 \%$, that is one out of three people has hypertension. ${ }^{13}$

The valuable lesson learnt is that lifestyle intervention in the year 1993-2000 effectively reduced the prevalence of hypertension by $4.3 \%(16.5 \%-12.2 \%) 4.3 \%$ or 0.6 $\%$ per year. If we carry out these lifestyle interventions in the year 2019, the prevalence of hypertension might be reduced by 3\% or higher. Data in the year 2007 showed that only $61 \%$ was treated with medication and only $33.3 \%$ reached the target blood pressure might present as a challenge to combat hypertension, further campaigns and intensifications might be needed.

\section{Obesity}

The prevalence of obesity increased alarmingly in every consequent survey using both WHO (BMI > $30 \mathrm{Kg}$ / M2) criteria as well as Asian ( $\mathrm{BMI}>27 \mathrm{Kg} / \mathrm{M} 2$ ). The

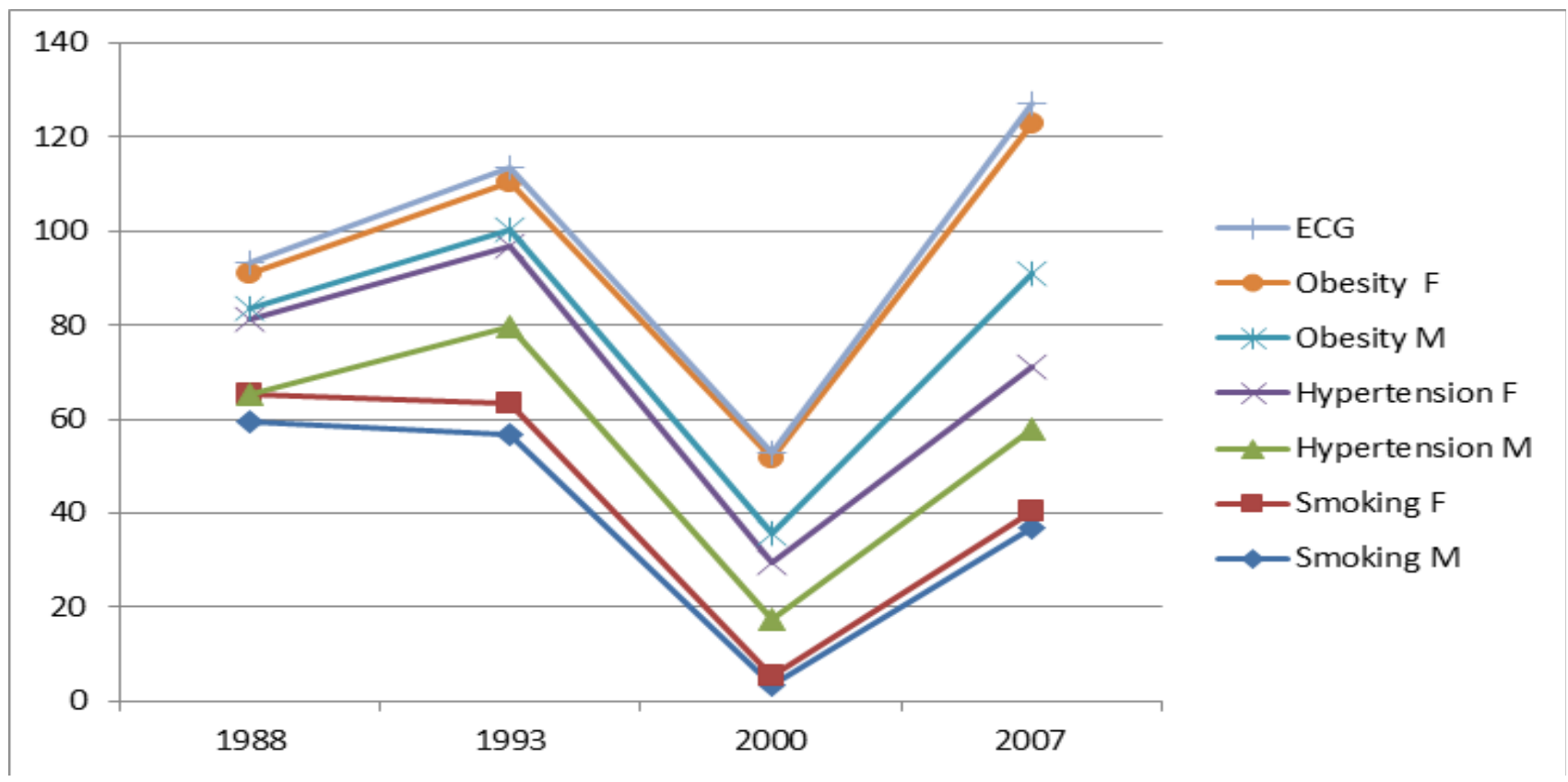


prevalence for obese male was 2,3\% (1988), $3.7 \%$ (1993), $6.1 \%$ (2000), and 19,8\% (BMI >27 kg/M2 )in 2007. The prevalence for obese female was $7.3 \%$, $10 \%$ and $15.9 \%$, and $31.8 \%$ respectively. The burden of obesity was higher in women. The cost of obesity on the healthcare system is substantial; an estimated $\$ 147$ billion in medical costs were attributed to obesity alone in the US in 2008. Furthermore, the prevalence of childhood and adolescent obesity, which now affects $17 \%$ of children and adolescents, raises concerns for its impact on adulthood obesity and long-term health outcomes. ${ }^{14}$ The prevalence of obesity in Indonesia might be influenced by GDP which is steadily increasing in the early 90 s before exponentially increasing few years after reformation in $1998 .{ }^{15}$ This increase in obesity nearly mirrors the explosive rise of obesity prevalence to 3 times in the year 2007 compared to 2000. A study showed an association between GDP and obesity which then plateau after GDP reached a specific level. ${ }^{16}$

Overcoming obesity is challenging and multilevel and disciplinary approach is needed to formulate an effective intervention.

\section{Diabetes}

The data for blood sugar and diabetes in the year 1988, 1993, and 2000 was unavailable. The 2007 survey defined diabetes as fasting blood glucose $>126 \mathrm{mg} /$ $\mathrm{dL}$ yielded a prevalence of $9.8 \%$ in male and $9.89 \%$ in female. Riskesdas 2018 showed a rising prevalence from $6.9 \%$ in the year 2013 to $8.5 \%$ in $2018 .{ }^{13}$

Third National Health and Nutrition Examination Surveys (NHANES III, 1988-1994) and subsequent 2-year NHANES cycles up to 2008 to define trends and forward projections to 2020 in CV health behaviours and factors. Time trends were estimated using weighted linear regression, adjusted for age, and projections were calculated assuming that trends would continue at a similar linear rate. Data from 35,059 NHANES CV disease-free participants aged $\geq 20$ years (mean age: 44.4 years; $51 \%$ women) showed substantial increases in obesity (from 20\% in 1988 to $32 \%$ in 2008) and poor or intermediate levels of glucose/diabetes control (from $21.1 \%$ to $42.9 \%) .{ }^{14}$

Obesity and Diabetes were intimately associated, and these issues should be addressed concurrently.

\section{Physical Activity}

Monica Jakarta Survey and Jakarta Cardiovascular Study also investigated physical activity, 51\% of the respondents participated in regular sports activity on the year 1988 which decreased to $49.7 \%$ on 1993 before rebounding to $68 \%$ on the year 2007 . Female participated in regular sport more frequently than male counterpart (64.9 vs $35.1 \%$ ).

Although these data showed a contrasting relationship between physical activity and other cardiovascular risk factors, showing as if obesity and hypertension were not reduced with regular sports. Studies have shown that exercise and reduction of sedentary behaviours are an integral component to mitigate the genetic predisposition to increased BMI. ${ }^{14}$ The counterintuitive data might be explained by other possibilities such as the questionnaire should also indicate the intensity, duration, and frequency of exercise activity on a weekly basis. There are other factors influencing the risk factors including the aforementioned GDP and other factors such as food intake.

\section{Abnormal ECG}

Old myocardial infarction was prevalent in $2.8 \%$ in the year $1988,2.9 \%$ in 1993 , decreased to $1.2 \%$ in 2000 and increased to $5.2 \%$ in the year 2007 .

\section{Conclusion}

On a modern day, the prevalence of smoking dwindled compared to that of the past, forming a downtrend pattern. However, hypertension, obesity, and diabetes were more prevalent compared to the 1990s. Sports and physical activity was shown to be higher. A joint-effort by the medical society, government, legislation, social activists, and public figure should be made in order to modify the prevalence of these cardiovascular risk factors.

\section{Acknowledgements}

The author would like to thank Dr.Soekaman , SpJP(K),Prof. dr. Boedhi-Darmojo, Sp.PD(K), Sp.JP(K); the Head of the Cardiology Department/ 


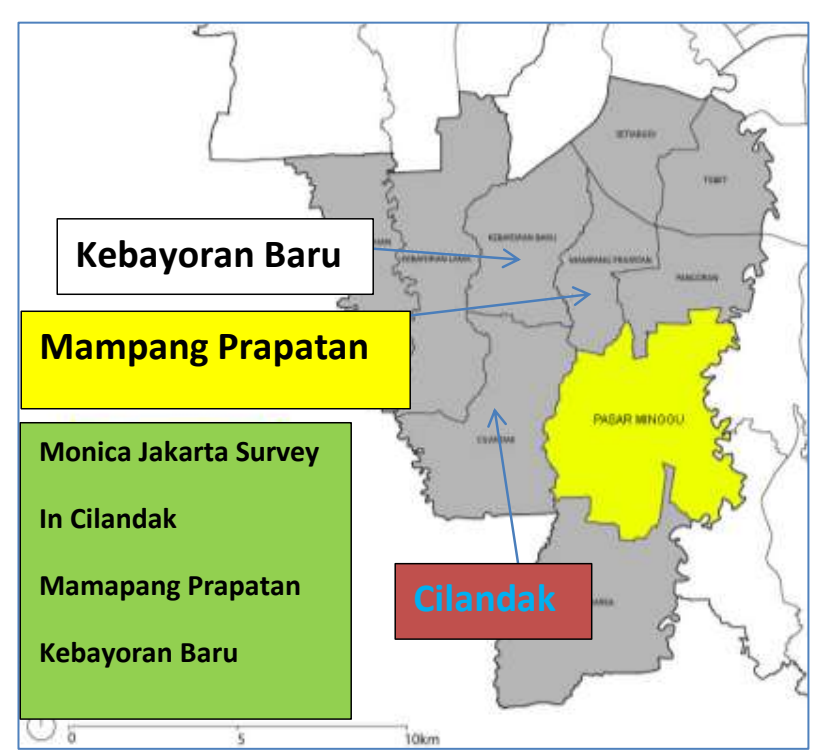

Harapan Kita National Cardiovascular Centre; the Director of Harapan Kita National Cardiovascular Centre; all community doctors from the district hospitals - Mampang Prapatan, Cilandak and Kebayoran Baru; the investigator team of the MONICA Jakarta project; Jakarta Cardiovascular Study . all colleagues, cardiology residents, nurses, paramedics, health-personnel for their valuable support and participation in these study.

\section{References :}

1. Syed S. Mahmood, Daniel Levy, Ramachandran S. Vasan, and Thomas J. Wang The Framingham Heart Study and the Epidemiology of Cardiovascular Diseases: A Historical Perspective. Lancet. 2014 Mar 15; 383(9921): 999-1008. Published online 2013 Sep 29. doi: [10.1016/S0140-6736(13)61752-3].

2. Reddy KS, Yusuf S. Emerging epidemic of cardiovascular disease in developing countries. Circulation 1998;97:596-601.

3. Djaja S, Soemantri S, Miharja L, Setyowati T. Pola sebab kematian di Indonesia. Survei Kesehatan Rumah Tangga (SKRT). Badan Litbangkes Departemen Kesehatan RI; 1995.

4. Miharja L, Soemantri S, Djaja S, Setyowati T. Mortalitas penyakit kardiovaskular serta beberapa faktor risiko yang berkolerasi. Seri Survei Kesehatan Rumah Tangga; 1997.

5. Kannel WB, McGee DL, Castelli WP. Latest perspective on cigarette smoking and cardiovascular disease. The Framingham study. J Cardiac Rehab
1984;4:267-77.

6. Levy D, Wilson PWF, Anderson KM, Castelli WP. Stratifying the patient at risk from coronary disease. New insights from the Framingham Heart Study. Amer Heart J 1990;119 (suppl 3):712-17.

7. WHO expert committee. Community prevention and control of cardiovascular disease. Report no TRS 732. Geneva: WHO, 1986.

8. Mancia G. The need to manage risk fâctors of coronary heart disease. Am H J 1988;15: 240-2.

9. Boedhi-Darmojo R, Karim S, Sutedjo, Setianto B, Kusmana D, dkk. MONICA Jakarta survei kedua 1993/1994 dalam: Sutedjo dkk. Presentasi dan diskusi survei II MONICA Jakarta 1993; 1994 Des 20; Jakarta; Badan Litbang Depkes RI, Pusat Kesehatan Jantung Nasional RS. Jantung Harapan Kita: 1994.

10. Kusmana D, Basuki B , and Jakvas Team . Jakarta Cardiovascular Study. Report Division of Research and Development, Dept of Cardiology and Vascular medicine, National Cardiovascular Center, Harapan Kita , Jakarta 2007.

11. Wang Q, Shen JJ, Sotero M, Li CA, Hou Z.Income, occupation and education: Are they related to smoking behaviors in China? PLoS ONE 2018;13(2): e0192571. https://doi.org/10.1371/ journal.pone. 0192571

12. Literacy rate, adult total (\% of people ages 15 and above). (n.d). Retrived from https://data.worldbank. org/indicator/se.adt.litr.zs on 22 March 2019

13. Departemen Kesehatan Republik Indonesia. Potret Sehat Indonesia dari riskesdas In: RISKESDAS 2018. http://www.depkes.go.id/ article/view/18110200003/potret-sehat-indonesiadaririskesdas-2018.html

14. Ruijun C, Purav SM, Aakriti G,Behnood B, Rachel D. Most Important Outcomes Research Papers on Body Weight, Obesity and Cardiovascular Outcomes In: Cardiovascular Quality and Outcome . https://ahajournals.org/doi/10.1161/ CIRCOUTCOMES.113.000681

15. GDP per capita (current US\$). (n.d.). Retrieved from https://data.worldbank.org/indicator/ NY.GDP.PCAP.CD on 22 March 2019.

16. Egger G, Swinburn B, Islam FM. Economic growth and obesity: an interesting relationship with worldwide implications. Econ Hum Biol 2012;10(2):14753. doi: 10.1016/j.ehb.2012.01.002. 